\title{
Raphaël Lemkin, Genocide, Colonialism, Famine, and Ukraine
}

\author{
Douglas Irvin-Erickson \\ George Mason University
}

\begin{abstract}
Many words have been used to name and describe the Great Ukrainian Famine of 1932-33, including "famine" and "catastrophe," "the Holodomor," and now "genocide." Was the famine genocide? Was the famine part of a genocide? Is the word genocide an exaggeration? Is naming the famine a genocide part of an attempt to dramatize events for political purposes today? Is the refusal to call the famine a genocide an act of genocide denial? This article argues that, though more than seven decades have passed and the Soviet Union has come and gone, questions about genocide in Ukraine remain intertwined in the discourses and narratives surrounding conflicts over Ukraine's economic, political, social, and cultural position between the European Union and the Russian Federation. Given the implications of this word-"genocide"-within the context of current conflicts over Ukrainian history and identity and even sovereignty, it is important to reflect on how this concept has been used and applied. This paper analyzes conflict in Ukraine in the 1930s using Raphaël Lemkin's definition of genocide, as opposed to the legal definition established by the UN Genocide Convention, and discusses the conceptual strengths of Lemkin's definition of genocide in terms of understanding a widespectrum of oppressive, repressive, and violent processes of empire-building and colonization that occurred in Ukraine, and which culminated in the Holodomor.
\end{abstract}

Keywords: Ukrainian famine, Holodomor, genocide, empire, Raphaël Lemkin.

\section{INTRODUCTION $^{1}$}

O

ver the last eighty years, there have been many words used to name and describe the Great Ukrainian Famine of 1932-33. Throughout the 1930s, foreign language newspapers used the terms "famine" and "catastrophe," and the event came to be known later as "the Holodomor." The rise of new terminologies in international law-such as terror, crimes against nations, crimes against humanity, and genocide-expanded the lexicon for describing the famine in Ukraine in scholarly and popular

\footnotetext{
1 This paper was delivered in Kyiv, Ukraine, on 5 June 2017, at the conference hall of the Ukrainian House. Portions of the paper draw on my biography of Raphaël Lemkin, published by the University of Pennsylvania Press, and my article on Lemkin (IrvinErickson, Raphaël Lemkin and the Concept of Genocide; Irvin-Erickson, "Genocide, the 'Family of Mind'”).
} 
discourses. Perhaps the most contentious of these appellations has proven to be "genocide."

Was the famine genocide? Was the famine part of a genocide? Is the word "genocide" an exaggeration? Is naming the famine a genocide part of an attempt to dramatize events for political purposes today? Is the refusal to call the famine a genocide an act of genocide denial? These questions generate intense scholarly controversy and mobilize political action amongst activists on all sides (see Naimark). Even though more than seven decades have passed and the Soviet Union has come and gone, questions about genocide in Ukraine remain intertwined in the discourses and narratives surrounding conflicts over Ukraine's economic, political, social, and cultural position between the European Union and the Russian Federation, and the armed conflict that began with the Russian invasion of Ukraine and annexation of Crimea in 2014 (see Irvin-Erickson, "Genocide Discourses").

Given the implications of this word-"genocide"-within the context of current conflicts over Ukrainian history and identity and even sovereignty, it is important to reflect on how this concept has been used and applied. The word "genocide" was coined by the Polish Jewish jurist Raphaël Lemkin late in the winter of 1941-42 and first appeared in print in Lemkin's magnum opus Axis Rule in Occupied Europe. In Axis Rule, which was fundamentally about the German occupation of Poland (see Rabinbach), Lemkin did not intend to establish a typology of what all genocides were, nor did he maintain that the case of genocide perpetrated by Germany under Nazi rule in the 1930 s and 1940s was the prototypical case of genocide. Rather, he saw the Holocaust as one of many genocides across history.

Indeed, Lemkin's thinking on genocide was inspired by the social and intellectual milieu in which he was born. He was raised in a Jewish family on a farm in imperial Russia, in a region he described as "historically known as Lithuania," which became part of independent Poland, passed into Soviet hands, and is now part of Belarus (Lemkin, Autobiography). Growing up in a multi-cultural, multi-ethnic, and multi-religious milieu, Lemkin, like many of his peers, was raised speaking Russian, Yiddish, and Polish as first languages. He became fluent in Hebrew and German in early childhood, as well as in local dialects of Russian and Belarusian, and by early adulthood, had added French, English, Spanish, and Italian to his repertoire. Lemkin understood what it felt like to be a minority in an oppressive nation-state, where belonging and basic citizenship rights, including the right to life, were awarded by states to individuals according to their national identity - and where state policies were often set towards the goal of eradicating entire identity-based social groups, erasing not just the individuals but also their cultural imprints. Lemkin understood, acutely, the value of human diversity but also that human societies did not automatically value diversity. Instead, 
cosmopolitan sensibilities had to be created and defended. He believed, therefore, that it was necessary to safeguard the institutions and values that allow individuals to be free to express their own subjective identities, to be curious about others' identities and cultures, and to integrate the contributions and identities of others into their own (see Bronner). It was this dynamism between the ideas and cultures of national groups, Lemkin believed, that allowed human creativity to flourish, enriching the lives of individuals and world civilization as a whole. Genocide, Lemkin thought, is intended to destroy such a world: to stamp out differences in the name of creating homogeneous communities where individuals who hold different identities are repressed, marginalized, exiled, or even killed, and to restrict the participation in public life of individuals who belong to subaltern or minority groups.

Lemkin did not classify the famine in Ukraine as a genocide. Rather, he saw the famine as the most brutal stage of a genocide. Indeed, for Lemkin, genocide was about destroying what he called the national patterns of the oppressed, what we might today call their social identities. Thus, for Lemkin, the Soviet genocide against the Ukrainian nation began long before the first individuals were killed. Famine is a particularly effective means of committing genocide, Lemkin believed, not only because of the large number of individual deaths it achieves but because hunger and starvation shatter the social bonds between families, friends, and communities. In Lemkin's mind, what makes starvation such an effective tool for destroying social groups is that hunger pits members of a social group into competition for survival, ensuring that the bonds of trust, friendship, and love that hold a social group together, and which form the basic content of an individual's social identity, are shattered.

\section{PART 1: LEMKIN ON GENOCIDE AND COLONIALISM}

To understand Lemkin's thoughts on famine as a technique of genocide, it is necessary to first outline Lemkin's definition of "nation" - the entity he asserted that genocide destroyed. It is also worth noting what Lemkin thought perpetrators of genocide sought to gain by destroying nations"genocide as a form of inter-group conflict and a fundamentally colonial act. ${ }^{2}$

Genocide, Lemkin wrote in Axis Rule, was "a coordinated plan of different actions aiming at the destruction of essential foundations of the life

\footnotetext{
2 This line of inquiry, in which Lemkin conceptualized the Soviet genocide in Ukraine as a form of colonial conflict, can contribute to new directions in Soviet studies that employ the concepts of empire and colonization to understand the Soviet Union. See Annus; von Hagen.
} 
of national groups, with the aim of annihilating the groups themselves" (79). Lemkin conceived of genocide as having two phases: "One, the destruction of the national pattern of the oppressed group; the other, the imposition of the national pattern of the oppressor" (Axis Rule 79). "Directed against the national group as an entity," he wrote, "the actions involved" in committing genocide "are directed against individuals, not in their individual capacity, but as members of the national group" (Lemkin, Axis Rule 79). Lemkin thus interpreted the genocide perpetrated by Nazi Germany as a colonial project of transforming the demographics of Germany and the newly conquered regions of occupied Europe. "In line with this policy of imposing the German national pattern, particularly in the incorporated territories, the occupant has organized a system of colonization of these areas," Lemkin wrote (Axis Rule 83). As a consequence of this colonization, Lemkin concluded that "participation in economic life is thus dependent upon one's being German or being devoted to the cause of Germanism. Consequently, promoting a national ideology other than German is made difficult and dangerous" (Axis Rule 86).

Lemkin's was not an unprecedented analysis of the German occupation of Europe. Newspapers and political and popular discourses throughout Eastern Europe commonly referred to the German occupying army as a colonizing force. ${ }^{3}$ Lemkin's ideas were also strikingly similar to those espoused by the theorist Otto Bauer, whom Lemkin identified as a major influence on his thinking. "Modern imperialism" does not seek a unified world, Bauer wrote in his classic book The Question of Nationalities and Social Democracy (published in 1907 and republished in 1924), but rather "encloses the economic zone of the individual country within a customs border" that opens up the less developed country as a sphere of investment and sales for the capitalists of the developed country (379). Modern imperialism, therefore, "does not dream of freedom, but prepares for war," Bauer contended, because the modern nation-state "does not believe in the possibility of uniting the whole of humanity in free and peaceful exchange" but "seeks to help its own land at the cost of the other by arming itself with tariffs, with navies, and with soldiers against other countries" (379). The primary goal of state militaries, Bauer argued, was not only to defeat other armies in battle but to eliminate national groups whose way of life hindered capitalist expansion into new markets. These violent processes of destroying nations as sociological entities were most pronounced in Eastern Europe and in European colonies, Bauer wrote. The armies that were raised by nation-states, Bauer continued,

${ }^{3}$ See, for example, Korostelina, for the Crimean Tatar discourse. 
must be ready and willing to be used, today in African and tomorrow in India, today to exterminate a Negro tribe root and branch and tomorrow to struggle against the white soldiers of another nation. Today they must protect the owners of large gold mines against the rebellion of their foreign workers and tomorrow dispense bloody punishment to the Egyptian peasants for beating their arrogant conqueror. (390)

Yet it was not enough that the armies of nation states had to be willing to inflict such brutality. Bauer suggested that the citizens of nation states must "desire" to subjugate, enslave, and destroy entire nations of less developed others in the name of their nation. Thus, state elites exploit racism and national chauvinism to legitimize the attempt to destroy nations and national ways of life that impede the expansion of capitalist forms of social organization. Remarkably, Lemkin would argue that the Soviet regime under Stalin was conducting a similar program to eradicate entire national ways of life to advance their modernizing, economic program. Lemkin's definition of genocide clearly borrowed heavily from Bauer (see Irvin-Erickson, Lemkin).

\section{Genocide as the Destruction of Nations}

If genocide was the destruction of nations and national patterns, what was a nation according to Lemkin? Here again, Lemkin borrowed heavily from the Austro-Hungarian theorists and political figures Karl Renner and Otto Bauer.4 Bauer had argued that modern nations were "communities of character" that developed out of "communities of fate" (7). For Bauer, nations were not derived territorially, as liberal nationalism professed, nor were they the closed off and organic entities that conservatives (and German Romantic theorists) believed them to be. For Bauer, national consciousness was "by no means synonymous with the love of one's own nation or the will for the political unity of the nation"- "national consciousness is to be understood as the simple recognition of membership in the nation" (120). This also meant that the content of national identity was always changing because both nationality and nations as social groups were products of the consciousness of individuals (Bauer 21). Thus for Bauer, nations were neither trans-historical nor primordial entities but constantly changing as individuals themselves changed and as new "communities of fate" formed and developed into new "communities of character" (109). Consequently, national identity was not a zero-sum game, and national identities were not mutually exclusive. Lemkin would borrow these ideas explicitly in his late,

\footnotetext{
4 See Renner, especially 30 and 39. Compare this to Lemkin's correspondences with Renner. Raphael Lemkin to Karl Renner, March 29, 1950, Raphael Lemkin Papers, American Jewish Association, Cincinnati, Ohio, United States. Box 1, Folder 15.
} 
unpublished writings on genocide and quietly announced this position in a footnote in Axis Rule (91n5).

In contrast to Lemkin's understanding of what nations were, developed from the social and political theory of Bauer and Renner, orthodox Marxist positions and transcendentalist or neo-Kantian liberal thinkers saw nations as categories, derived from either materialist or spiritual theories of history (Nimni 162). For Bauer and Renner, nations were historical processes rather than categories (Nimni 162-63). Bauer's definition of a nation as "a community of character formed out of a community of fate" does not locate the nation purely in the realm of psychological consciousness, where communal bonds are formed through abstract notions of solidarity, nor does it locate the nation within materialist thinking. At the same time, because nations existed within the consciousness of individuals who recognized the existence of nations, nations took on objective social characteristics. However, nations constantly reformed as new communities of fate formed and created new communities of character. Indeed, Bauer argued, nations could not be identified by empirical theorists who defined the essential characteristics of a nation in the abstract and then looked at the real world to see whether or not a given group constituted a nation (Nimni 161).

A nation, according to Lemkin, was above all a collection of individuals who thought of themselves as belonging to the same group, with the help of shared languages, arts, mythologies, folklores, collective histories, traditions, religions and even shared ancestry or a shared geographical location. Languages, lineages, pseudo-scientific theories of biology, religions, and geography - these only created the boundaries of national groups when people believed that these things mattered. Importantly, this principle meant that a given individual could belong to more than one nation at the same time since the criteria for establishing nations were not mutually exclusive. Individuals could enter into and out of certain "families of mind" throughout their lives or could express one identity at one time and another at another time, or multiple national identities at once. Within this conception, no individual could ever be fully representative of a nation; nor could any individual be reduced to a nation.

It was for this reason that Lemkin considered many different kinds of groups to be "nations," believed that nations were constituted by people's recognition that they were part of a nation, argued that nations were always changing their national character and that this dynamism enriched the lives of individuals, and felt that each individual could hold many different national identities throughout his or her life-oftentimes holding several at once. Lemkin even posited that under the rubric of "nations," various sociological groups could be included, such as "those who play cards, or those who engage in unlawful trade practices or in breaking up unions." Genocide, Lemkin reasoned, could be conducted against criminals because 
states often criminalized certain types of subjectivities and ethnic identities. After all, he argued, had not the Soviet Union conceived of counterrevolutionary forms of national consciousness as criminal?

What then for Lemkin was genocide? His definition was simple. Genocide was the destruction of nations, which entailed the destruction of the national patterns of the oppressed group and the imposition of the national patterns of the oppressor. This definition is remarkably different from the definition of genocide found in the UN Genocide Convention, which reads:

\section{Article I}

The Contracting Parties confirm that genocide, whether committed in time of peace or in time of war, is a crime under international law which they undertake to prevent and to punish.

\section{Article II}

In the present Convention, genocide means any of the following acts committed with intent to destroy, in whole or in part, a national, ethnical, racial or religious group, as such:

(a) Killing members of the group;

(b) Causing serious bodily or mental harm to members of the group;

(c) Deliberately inflicting on the group conditions of life calculated to

bring about its physical destruction in whole or in part;

(d) Imposing measures intended to prevent births within the group;

(e) Forcibly transferring children of the group to another group.

\section{Article III}

The following acts shall be punishable:
(a) Genocide;
(b) Conspiracy to commit genocide;
(c) Direct and public incitement to commit genocide;
(d) Attempt to commit genocide;
(e) Complicity in genocide. (United Nations Convention)

A discussion of how the United Nations Genocide Convention of 1948 came to define genocide is beyond the scope of this paper, but it is an issue I consider at length in my book on Lemkin and the concept of genocide (Raphaël Lemkin). Suffice it to say that Lemkin's ideas on genocide were largely rejected by the major powers at the UN, who did not want to outlaw attempts to destroy national patterns and whose delegates sought to 
preserve the right of their governments to oppress minorities within their own borders. ${ }^{5}$

For Lemkin, genocide was not necessarily an act of mass murder, though mass murder could be genocide if the act was committed with the intention of destroying a nation. Instead, genocide was about destroying a nation. If genocide was the destruction of nations and national patterns, then genocide for Lemkin was very much the destruction of "families of mind" as well as the destruction of social processes by which "communities of character" formed from "communities of fate." As such, in Lemkin's conceptualization, genocide could be achieved through direct and indirect violence or through forms of repression that could be called in today's parlance "structural violence" (see Galtung). In fact, under Lemkin's definition, genocide could be achieved without the death of a single individual-if the social processes of group formation of "families of mind" were targeted for destruction, leaving individual people alive but permanently altering their social identities and national patterns, making the social reproduction of the group impossible.

\section{PART 2: LEMKIN ON THE SOVIETS}

Lemkin coined the word genocide in 1941, but his thinking on the destruction of nations can be traced to the late 1920s. In 1926, at the age of 26, Lemkin published his first book, Kodeks karny republik sowieckich (The Penal Code of the Soviet Republics). When the book was released, he had just graduated with his doctorate in Law from Jan Kazimierz University in the capital of Galicia, Lviv (known as Lwów in interwar Poland). The book contained the first Polish translation of the Soviet penal code. In his commentary, Lemkin briefly addressed Stalin's nationalities policies while dealing mainly with the historical evolution of the Russian and Soviet penal codes. In 1928, the speaker of the Polish parliament, Wacław Makowski, wrote the introduction to Lemkin's next book, Kodeks karny Rosji Sowieckiej 1927 (The 1927 Criminal Code of Soviet Russia). In his analysis of the 1927 penal code, Lemkin noted that the reforms made to the Soviet penal code after Lenin's death marked no substantive difference from the laws Lenin's party enacted in 1922. The only difference, he wrote, was that the new code drew on nineteenth-century Italian Positive legal theory to explicitly codify "social protection" as the purpose of the law. This small but crucial observation would remain a central component of his study of genocide and the law; he saw genocide as legitimized through laws that allowed for the

\footnotetext{
${ }^{5}$ Weiss-Wendt makes it perfectly clear, for example, that the Soviet delegation had far more influence on the definition of genocide as it became codified in the law than Lemkin did.
} 
removal of ethnic and national minorities from society under slogans of social protection.

Lemkin's commentary on the Soviet penal code explicitly examined Lenin's policy of using Soviet law as a component of the dictatorship of the proletariat. The Soviet system conceived of the law as a form of social protection, Lemkin wrote, not simply a system to punish individual crimes ("Dzieje"; see also Kornat 98). The law, in this formulation, legitimized the arrest, suppression, oppression, and killing of people who had a social consciousness that was deemed criminal, Lemkin wrote. In the Soviet context this criminal social consciousness was called "enemy nationalism." The Soviet Union was solving its "nationalities problem" by legalizing the suppression, repression, and elimination of entire social groups who had forms of social consciousness that the ruling elites believed were threats to state power and could be a countervailing force to the revolution. The Soviet legal code, Lemkin wrote, was therefore not merely a tool for maintaining the gains of the proletarian revolution; the law was a means for educating the proletariat in the new social order and actively supported the creation of the new communist system by sanctioning the state violence and coercion necessary for the destruction and transformation of the bourgeoisie and national minorities into Soviet citizens ("Ustawodawstwo" 7; see also Kornat 98). The goal of this state-directed force was to create, destroy, and reorganize social relationships by managing the identity of Soviet populations in a way that was perceived as benefitting the Soviet revolutionary project or the state itself (Feierstein 1). From the ashes of the old bourgeois and peasant identities, a new social identity would be created as a matter of state policy-Homo Sovieticus. The new Soviet Man, as Stalin called this new social identity, would hold no allegiances to previous national identities but would demonstrate a consciousness amenable to the socialist program.

In the late 1920s Lemkin had not yet proposed the term genocide and would not coin the neologism until almost two decades later. Still, the origins of Lemkin's ideas can be traced to his early writings. What is striking is that Lemkin's focus was not on mass killing but rather on the way the social identities or national patterns of individuals and groups living in states was seen as a primary security concern for states and governments. By the time Lemkin published Axis Rule, he was ready to argue that the nature of armed conflict in the modern world had fundamentally changed. Warfare was no longer conducted between armies but between armies and populations. In his History of Genocide-an unfinished three-volume world history of genocide he was writing when he died-Lemkin traced the origins of this development in the colonial Spanish conquests in the Americas and the European conquests in South Asia and Africa. Modern warfare, he argued in Axis Rule and in his History, was defined by state (or state-like) actors using institutions, security forces, and armies to wage war against civilian 
populations, with the goal of transforming "the human element" of societies within the borders they sought to govern and rule (Irvin-Erickson, Raphaël Lemkin 77).

A second important development in Lemkin's ideas on genocide occurred in October 1933, when he authored a paper proposing the outlawing of the crimes of "barbarism" and "vandalism" under international humanitarian law at the League of Nations ("Akte der Barberei" 117-19). At that time, Lemkin wrote, his colleagues at the Association Internationale de Droit Pénal and many of his friends were discussing Mein Kampf and believed the German chancellor intended to carry out pogroms against Jews and institute a regime of biological national purity (Totally Unofficial 21). "Now was the time to outlaw the destruction of national, racial, and religious groups," Lemkin wrote, describing his sense of urgency to begin working with the Association (Totally Unofficial 22). Building on his works on the Soviet penal code, the proposal was Lemkin's first attempt to prevent the destruction of nations (Segesser and Gessler). He intended to deliver his paper at the Fifth Conference for the Unification of Penal Law in Madrid in 1933 (Lemkin, "Les Actes" 48-56).

Lemkin's paper listed five "new types of crimes," which he argued to be included as part of the laws of nations:
a) barbarity
b) vandalism
c) provoking catastrophes in international communication
d) disrupting international communication
e) spreading human, animal, or vegetable contagion.

In his text, Lemkin credited Vespasian V. Pella with creating the concepts of barbarity and vandalism, citing papers delivered by Pella and Henri Donnedieu de Vabres. Pella had used these concepts in his 1929 proposal to outlaw currency counterfeiting (Lewis 188). ${ }^{6}$ Lemkin's writings gave the words theoretical content that Pella had not provided (see Jiménez de Asúa et al.). Scholars have shown that Lemkin's unique intellectual contribution was to apply the principles of universal jurisdiction to these new crimes, linking the legal conception of terrorism to the practice of state violence targeting national minorities. This was a direct response to the Nazi rise to power and SA (the so-called Brownshirts) terror unleashed against Jews in Germany, as well as Soviet terror (Kraft; also see Troebst).

Mark Lewis has suggested that Pella primarily wanted to use

\footnotetext{
${ }^{6}$ See League of Nations, Proceedings of the International Conference for the Adoption of a Convention for the Suppression of Counterfeiting Currency, Geneva, April 9th to 20th, 1929 (Geneva), C.328.M.114.1929.II, pp. 52-55.
} 
international law to protect the Versailles system of borders against the rising aggression of Hungarian and Italian nationalist movements and what he saw as a communist movement in the Soviet Union that would eventually threaten to engulf central European states. Lemkin, on the other hand, wanted to deal with the breakdown of the League of Nations system by expanding international criminal law to protect vulnerable minority populations from persecution and destruction, while extending international criminal law to cover crimes committed by state officials against their own populations in times of formal peace (Lewis 295; see also Müller; Troebst).

As he prepared for the conference in Madrid, Lemkin expected a "big fight" (Totally Unofficial 23). Gazeta Warszawska (Warsaw Gazette), an influential anti-Semitic Warsaw newspaper, came out against his paper in its 25 October 1933 issue after the conference. The newspaper accused Lemkin of acting in the interests of his Jewish race and not the Polish nation. At the time, Poland was seeking non-aggression pacts with both Stalin and Hitler. Wishing not to antagonize the two powers, the Polish government blocked Lemkin from leaving the country. In what appears to be a blatant case of antisemitism, Lemkin was denied travel documents and prevented from presenting his ideas. ${ }^{7}$ Without his presence, his proposal to outlaw barbarity and vandalism was tabled without debate. Within weeks, Lemkin was forced to resign from his public posts.

In the paper Lemkin intended to deliver in Madrid, he articulated a need for international humanitarian law to prevent the purposeful destruction of works of culture that represented the specific genius of national and religious groups and to protect the physical and spiritual life of nations and people ("Les Actes"). He defined barbarism as the attempt to destroy ethnic, religious, or social collectivities. Lemkin also included in this category brutalities that strike at the lives and dignity of individuals as part of a campaign to exterminate the collectivity in which the victim is a member ("Les Actes"). A systematic and organized assault against whole populations, barbarism encompassed pogroms, massacres, mass rape, forced removal of populations, forced adoptions, and cruelties designed to humiliate the victims, or even attempts to destroy the economic existence of the members of a collectivity in order to destroy the collectivity. Vandalism, Lemkin wrote, was an attack targeting a collectivity taking the form of a systematic and organized assault against the heritage or unique genius and achievements of a collectivity. Vandalism was the crime of destroying a group's cultural works, including libraries and art, but also their unique rituals, ceremonies, and beliefs. The cultural creations, arts, and traditions of each nation and

\footnotetext{
${ }^{7}$ Why Lemkin was prevented from going to Madrid is disputed. For varying accounts see Korey; Power; Szawłowski.
} 
culture contribute to the enrichment of all humanity, Lemkin reasoned, and therefore belong rightfully to all humanity ("Les Actes"). Lemkin insisted the two crimes were intertwined in the process of attacking the physical and spiritual existence of nations. ${ }^{8}$

Lemkin's crimes of "barbarism" and "vandalism" are almost identical in form to his descriptions of Soviet terror in his discussion of the Soviet penal code, as if Lemkin were attempting to create an international law in 1933 that would apply to the political and legal conditions in the USSR. Andrei Vyshinskii, the Procurator General of the Russian SFSR, recognized this immediately. Vyshinskii-who was the mastermind of Stalin's show trials, orchestrated Stalin's notorious great purge in 1937, and went on to serve as the Soviet Minister of Foreign Affairs-accused Lemkin of attempting to create international laws that specifically targeted the Soviet Union. A decade later, Vyshinskii would square off a second time against Lemkin at the United Nations. In 1933, however, the Russian prosecutor general would call Lemkin's barbarism and vandalism part of a larger plot that Lemkin had been spinning for years on behalf of the capitalist powers to ensnare the USSR in a web of international law that could threaten the vitality of the revolution.

Lemkin grouped laws on barbarity and vandalism together with laws against state terrorism, piracy, slavery, pornography, narcotics trade, counterfeiting money, disrupting international communication, and spreading human, animal, and vegetable contagions. Vyshinskii believed this grouping was a ruse and denounced Lemkin for inventing laws intended to target actions of the Soviet Union under the pretense of creating a neutral, apolitical body of unified international laws. In the introduction of a book by Aron Trainin covering the international movement for the unification of penal law, Vyshinskii wrote that the unification movement never mentioned actual struggles "with international crooks and charlatans of any stripe, not the fight with the bandits like Al Capone," but instead focused on abstract concepts like "terrorism" (4). ${ }^{9}$ The concept of terrorism that these Western liberals claimed to be fighting, Vyshinskii continued, "turned into the central problem of the bourgeois unification movement" because it created the basis for limiting state sovereignty and "removing the state from its pedestal" (4). Vyshinskii went on to add that "no evasions and intricacies of such unifiers as Lemkin, who tried again to disguise the true purpose of the criminal interventionists with references to 'vandalism' and 'barbarism,' can mislead anybody," because "the true meaning of the unifiers' efforts is to legally and politically justify the right of the counter-revolutionary bourgeoisie to

\footnotetext{
8 Elsewhere, I have written about Lemkin's definition of nation. See Irvin-Erickson, "Genocide, the 'Family of Mind."”

${ }^{9}$ I thank Gennadi Pobereżny for helping me translate this text.
} 
intervene in the internal affairs of any state, under the pretext that they are concerned for the fate of 'culture and civilization'" (4-5).

What was it that Vyshinskii found so objectionable in Lemkin's thinking? In the existing laws of nations, Lemkin wrote, there were three categories of humanitarian protections. The first category corresponded to attacks on individual rights and included laws against slavery and laws to prevent people from being treated as commodities. The second category of offences related to the individual and the collectivity, and essentially amounted to minority rights treaties that he believed were fully inadequate and morally fraught. The third category concerned the relationship between two or more collectivities and encompassed offences against the laws of nations that seek to protect peaceful relations between collectivities, such as outlawing propaganda intended to incite wars (Lemkin, "Les Actes"). In his proposal to outlaw barbarity and vandalism, Lemkin offered another type of violationone that he believed was a hallmark of Soviet terror and the kinds of violence defining Nazi politics in Germany. This fourth category consisted of attacks committed against individuals with the intention of destroying a collectivity. In such cases, Lemkin wrote, the goal of the perpetrator is to harm an individual in a way that damaged the collectivity to which the individual belongs. These types of offences violate human rights, but also undermine the foundation of society (Lemkin, "Les Actes"). Yet in these matters, Lemkin believed, international law was silent precisely because the nature of armed conflict had changed with the rise of the horrors of colonial conflict in the nineteenth century and the advent of state security forces and armies across Europe that targeted their own civilians and treating minority populations as enemies of the state. As explained in Axis Rule, Lemkin intended to synthesize the ideas of "barbarism" and "vandalism" into the single conception of genocide.

\section{PART 3: LEMKIN ON HUNGER AND GENOCIDE}

If Lemkin defined genocide (and by extension "barbarism" and "vandalism") as the destruction of nations ("families of mind"), which involved the destruction or removal of the national pattern of the oppressed and the imposition of the national pattern of an oppressor-then it follows that Lemkin would be most concerned with acts that destroyed bonds of social solidarity that made group life and the social reproduction of groups possible. And indeed, this is precisely why Lemkin believed that in many cases, the destruction of libraries and the banning of folk traditions and religious customs could be acts of genocide, while large-scale acts of mass killing and massacres might not qualify as genocidal. What is so vicious about famine and hunger as a tool for committing genocide, Lemkin believed, is 
that this form of violence not only targeted large numbers of individuals but places the victims in competition with each other for their very survival. In turning the victims into enemies of one another, famine and hunger destroy the bonds of trust and solidarity within a society while inflicting permanent damage to the individual's sense of belonging and trust, which further serve to destroy the "family of mind."

In chapters 8 and 9 of Axis Rule, Lemkin noted that the first regulations against Jews issued across Europe were restrictions to their freedom of movement, property, and employment and the imposition of food rationing based on racial criteria. In Nazi-occupied Poland, Jews over the age of ten were required to wear a yellow Star of David on an armband, and laws were passed requiring all Jewish-owned enterprises and stores to have special signs visible to the public. Lemkin cited decrees such as a statewide ban on Jews using the Polish railroad, which accompanied new laws that physically removed Jews from public life and moved them into ghettos. In May 1941, a decree of the Führer implementing the 1935 Reich Nationality Code and the 1935 Act for the Protection of German Blood and German Honour in Poland concretized who would live and who would be consigned to die (Lemkin, Axis Rule 509). Lemkin established that these laws structured a set of interrelated developments that included racially motivated preferences in distributing food, the establishment of Jewish ghettos, the implementation of forced labour, and the development of concentration camps and extermination camps.

Lemkin argued in Axis Rule that Hitler and the Nazi Party had set out to commit genocide beginning in the 1930s, but the decision to kill the Jews and other victim groups en masse developed contingently as successive layers of laws and decrees and overlapping administrative structures shaped the political and social development of the genocide. He cited, for instance, Hermann Göring's 1941 order that people of German blood be given preference in access to foodstuffs (Lemkin, Axis Rule 87). Yet besides privileging Germans, the decree did not instruct the authorities on how to ration the food. Instead, the distribution of food corresponded to preexisting administrative regulations. The dynamic consequence was that German nationals had retained one hundred percent of their dietary requirement of carbohydrates and ninety-seven percent of their protein needs across the occupied territories. Ethnic Czechs obtained ninety percent of their nutrition needs, followed in diminishing order by the Dutch, Belgians, Poles in the incorporated territory, and then Poles in the nonincorporated territories, who all were receiving around seventy percent of their nutrition needs. At the bottom of the list were ethnic Greeks, who obtained only thirty percent of their daily nutrition needs, and Jews, who were subsisting on only twenty percent of their daily food requirements. In the Warsaw ghettos-where the Nazis enforced strict control over the 
distribution of food and artificially inflated the price of grains-German nationals remained well fed, but anemia rose one hundred and thirteen percent amongst ethnic Poles, and four hundred and thirty-five percent among Jews (Lemkin, Axis Rule 88).

Lemkin saw this discrimination in access to food as an element of a larger pattern of endangering the health of "undesired national groups" (Axis Rule 88n2). The occupying administrations throughout Europe withheld firewood and medicine from non-Germans in winter. In Poland during the fall of 1940, Hermann Göring decreed that all citizens of the former Polish state who did not have German blood had to turn over their property to the German occupying authorities (Lemkin, Axis Rule 511-16). During the winter of 1940-41, low-level officials requisitioned warm clothing, blankets, and heating fuel from Jews (Lemkin, Axis Rule 88). The efforts to physically endanger the health of the Jews was bolstered by the conditions in the ghettos where they were forced to live in crowded, inadequate housing. There were laws mandating that Jews who left the ghetto looking for food or shelter could be executed (Lemkin, Axis Rule 75). Prohibited from leaving the ghetto, Jews were thereby "denied the use of public parks" and "denied the right of fresh air," which was "especially pernicious to the health of children," Lemkin wrote (Axis Rule 88).

In Lemkin's analysis, the various techniques of genocide were always intertwined-whether they were physical or non-physical, or whether they were acts of direct violence or indirect, structural, and cultural violence. As such, Lemkin certainly saw both the physical death and the deterioration of the physical health of the targeted victims as acts intended to destroy the victim group. However, he was far more concerned with the destruction of Jewish social institutions and the effect of this destruction on the social cohesion and physical well-being of the Jewish "nation," or the Jewish "family of mind." Forcing Jews into the ghettos, in Lemkin's analysis, had brought about a near total annihilation of Jewish social life. Crowding, hunger, poor sanitation, and a violent typhus epidemic led to a twenty percent death rate, the disintegration of social solidarity, and the end of customs, traditions, and rites. The Jewish Council, or Judenrat, he argued, was used to shatter the bonds of the Jewish nation, as council members carried out Nazi directives targeting fellow Jews and were instructed to select which neighbours were sent to death camps, lest they themselves be killed. The Jewish Councils, and the slow deprivation of food and basic resources needed to sustain life, meant that the victims were now in competition with each other for survival. Victims viewed fellow victims as their enemies in conflict, which achieved two things for the perpetrators. First, it redirected resistance away from the perpetrators, and second, in turning victims against each other, it accelerated the destruction of the victim group, both physically and sociologically. 
It should be noted that it is not true that the Germans succeeded in reducing the Jews in ghettos to social-less beings (Corni). Still, many scholars have since substantiated what Lemkin gleaned from rumours and Nazi decrees: that waves of refugees, starvation, and disease did unravel social customs and cultural rituals, causing social cohesion and solidarity to break down in the Jewish ghettos across Europe (Goldberg 91-92). But this did not mean that Jewish social life or culture disintegrated in the ghettos. Lemkin knew there were resistance movements and armed uprisings (Norman Davies), but he did not know that many council members willingly accompanied their family members to the camps, refused to collaborate, or sabotaged Nazi plans (Trunk). He also did not know that underground support networks were set up to hide those most vulnerable to Nazi purges and to distribute contraband: food, fuel, and weapons (Gutman). Nevertheless, Lemkin believed that ghetto life had proven that the social, cultural, moral, and ultimately the physical and biological techniques of genocide could be orchestrated through very simple political and economic levers that deprived people of basic food and shelter. For this reason, Lemkin gave special attention to the laws governing economic life, for he believed they demonstrated that the seemingly disparate laws and decrees of the Axis rule actually formed an overlapping network orientated toward the destruction of national diversity. In this sense, the social and political aspect of ghetto life was not unique to the ghetto but a central facet of the broader genocide throughout the lands under Axis occupation. In the Netherlands, for instance, a provision to prevent Jews from opening bank accounts excluded them from the economy and undermined their social basis (Lemkin, Axis Rule 76). Across Europe, Lemkin demonstrated that Axis occupiers forbade Jews from being employed, prevented Jews from receiving state unemployment benefits, and made it illegal for Jews to receive money, food, and shelter from non-Jews. In the German-occupied Russian territories, Lemkin documented taxes that were put in place that essentially mandated that the salary paid to Jews would be entirely redirected to the state (Axis Rule 311). Even though these examples did not involve physically putting people in actual ghettos, the genocidal principle was the same, according to Lemkin. Jews were materially marginalized while the bonds of social solidarity were strained, with the goal of undermining the social basis of group life. In terms of hunger as a weapon of genocide, when life becomes a "daily fight literally for bread and physical survival," Lemkin wrote, "thinking in both general and national terms" becomes impossible as families, friends, neighbours, and communities begin to compete for food (Axis Rule 85). This destruction of group life, the shattering of these social bonds built on love and trust amongst family members and friends, cripples the ability of the victim group as a whole to fulfill the "cultural-spiritual requirements" of group life (Lemkin, Axis Rule 85). In such conditions, 
nations as families of mind could hardly exist. Hunger as a tactic for committing genocide not only killed people-it was a most effective means of destroying the national patterns of the targeted group.

\section{PART 4: UKRAINE}

In 1953, Lemkin spoke on the Ukrainian genocide at a commemoration of the Great Ukrainian Famine, known as the Holodomor (Luciuk; Serbyn, "Lemkin on Genocide"; Lemkin, Soviet Genocide in the Ukraine). Written two decades after the famine, the speech demonstrates the extent to which Lemkin's analysis of Soviet atrocities aligned with his early analysis of the Soviet terror, his work on barbarity and vandalism, and indeed his theory of genocide as the destruction of nations as "families of mind." The speech, delivered in 1953, should therefore be understood within the context of Lemkin's political and legal analysis of the Soviet regime that he developed in the early 1930s (Troebst).

In this speech, Lemkin considered Stalin's attempt to starve the peasantry as the most brutal attack against the Ukrainian nation. But the famine, for Lemkin, was the third stage in what he called a "four-pronged" genocide of the Ukrainian family of mind (Serbyn, "Ukrainian Famine"). "The first blow" of the genocide against the Ukrainian nation was "aimed at the intelligentsia, the national brain, so as to paralyze the rest of the body," he wrote (Lemkin, "Soviet Genocide" 3). Here, Lemkin was primarily addressing the Soviet targeting of individuals with violence and terror with the intention of destroying the social fabric of Ukrainian group life. "In 1920, 1926, and again in 1930-33, teachers, writers, artists, thinkers, [and] political leaders, were liquidated, imprisoned or deported . . . 51,713 intellectuals were sent to Siberia in 1931 alone.... At least 114 major poets, writers and artists, the most prominent cultural leaders of the nation, have met the same fate" (Lemkin, "Soviet Genocide" 1; also see Serbyn, "Lemkin on Genocide of Nations" and Irvin-Erickson, "Genocide, the "Family of Mind'"). What made these attacks genocidal was not that Stalin's regime killed so many people but that these individuals were killed with the purpose of destroying a distinctly Ukrainian "national pattern" or "family of mind."

A central concern for Lemkin in Axis Rule was the notion that the killing of individuals becomes genocide only when their killing contributes to the destruction of a group. He wrote that the object of genocide is to "annihilate the group themselves" through the "disintegration of the political and social institution of the culture, language, national feelings, religion, and the economic existence of national groups, and the destruction of the personal security, liberty, health, dignity, and even the lives of the individuals belonging to such groups" (Lemkin, Axis Rule 79). As discussed earlier, 
genocide could, in Lemkin's terms, be committed through what we might call indirect violence or structural violence, in addition to direct violence. In Lemkin's 1953 address during the commemoration of the Ukrainian famine, for example, he placed the Soviet genocide with the context of acts of the Soviet state intended to dismantle the functioning of the Ukrainian Orthodox and Ukrainian Catholic churches. This attempt to destroy the institution of the Ukrainian church-through arrests, forced conversion, disbanding, and killing-was the "second prong" of the genocide:

Going along with this attack on the intelligentsia was an offensive against the churches, priests and hierarchy, the "soul" of Ukraine. Between 1926 and 1932, the Ukrainian Orthodox Autocephalous Church, its Metropolitan (Lypkivsky) and ten thousand clergy were liquidated. In 1945, when the Soviets established themselves in Western Ukraine, a similar fate was meted out to the Ukrainian Catholic Church. That Russification was the only issue involved is clearly demonstrated by the fact that before its liquidation, the Church was offered the opportunity to join the Russian Patriarch at Moscow, the Kremlin's political tool. (Lemkin, "Soviet Genocide" 3)

Simply "for the crime of being Ukrainian,"

the Church itself was declared a society detrimental to the welfare of the Soviet state, its members were marked down in the Soviet police files as potential "enemies of the people." As a matter of fact, with the exception of 150,000 members in Slovakia, the Ukrainian Catholic Church has been officially liquidated, its hierarchy imprisoned, its clergy dispersed and deported. (Lemkin, "Soviet Genocide" 4)

Lemkin considered the Soviet assault on the Ukrainian clergy and intellectuals as genocidal because they are "attacks on the Soul" of the people that

will continue to have a serious effect on the Brain of Ukraine, for it is the families of the clergy that have traditionally supplied a large part of the intellectuals, while the priests themselves have been the leaders of the villages, their wives the heads of the charitable organizations. The religious orders ran schools and took care of much of the organized charities. (Lemkin, "Soviet Genocide" 4)

Lemkin's language of genocide as targeting the "soul" and the "brain" of a national group has been criticized as archaic and illiberal and has been interpreted to mean that he believed "that the murder of a poet is morally worse than the murder of a janitor, because the 'brain' without the 'body' cannot function" (Jones 11). While this is certainly a valid criticism, it should be remembered that Lemkin defined genocide "as directed against the national group as an entity," not individuals in their individual capacity (Axis 
Rule 79). Lemkin therefore considered the repression of the Ukrainian peasantry and its cultural and social intuitions to be as genocidal as the destruction of the Ukrainian intelligentsia and the Ukrainian church as long as the destruction of these social institutions, including the arrests and deaths of hundreds of individuals, was intended to destroy the Ukrainian "family of mind." Consider the following passage from Lemkin's speech on the Ukrainian genocide:

The third prong of the Soviet plan was aimed at the farmers, the large mass of independent peasants who are the repository of the tradition, folklore and music, the national language and literature, the national spirit, of Ukraine. The weapon used against this body is perhaps the most terrible of all-starvation. (Lemkin, "Soviet Genocide" 4-5)

Lemkin called the famine in Ukraine "the highpoint of Soviet cruelty" and took to task those who accepted unquestioningly "a Soviet economic policy connected with the collectivization of wheat lands" and thus dismissed the death of five million peasants ("Soviet Genocide" 5). He concluded by quoting Soviet government officials: "As a Soviet politician Kosior declared in Izvestiia on 2 December 1933, 'Ukrainian nationalism is our chief danger,' and it was to eliminate that nationalism, to establish the horrifying uniformity of the Soviet state that the Ukrainian peasantry was sacrificed" (Lemkin, "Soviet Genocide" 5).

For Lemkin, the interests involved were simple: the Soviet regime sought the "Russification" of the region in order to facilitate the rule of their state. The Ukrainian national identity, as distinct from a Russian identity, he argued, was a threat to the Soviet state and to the regime because the patterns of economic organization undertaken by people who held Ukrainian national identities were antithetical to the form of economic organization promoted by the state. ${ }^{10}$ For Lemkin, the Soviet interest in, and intention to commit, genocide was clear. The Ukrainians, with their ethnic traditions that pre-disposed them to pre-capitalist forms of economic social organization, made them bad Soviet citizens who resisted integration into the "modern" socialist economy. But Lemkin was also clear that grand visions of economic reform were not the only motivators of this genocide; the genocide against Ukraine generated income for the Soviet state: "A famine was necessary for the Soviets and so they got one to order, by plan, through an unusually high grain allotment to the state as taxes," Lemkin wrote. "Much of this crop, so vital to the lives of the Ukrainian people, ended up as exports for the creation of credits abroad" (Lemkin, "Soviet Genocide" 5).

10 Lemkin appears to be conflating Soviet with Russian. 
In Lemkin's assessment, these three "prongs" in the "systematic destruction of the Ukrainian nation, in its progressive absorption within the new Soviet nation" made the Soviet actions genocide (Lemkin, "Soviet Genocide" 6). While "there have been no attempts at complete annihilation, such as was the method of the German attack on the Jews," Lemkin wrote,

if the Soviet programme succeeds completely, if the intelligentsia, the priests and the peasants can be eliminated, Ukraine will be as dead as if every Ukrainian were killed, for it will have lost that part of it which has kept and developed its culture, its beliefs, its common ideas, which have guided it and given it a soul, which, in short, made it a nation rather than a mass of people. ("Soviet Genocide" 6-7)

Emphasizing the social destruction wrought by the famine, as hunger shattered social institutions, Lemkin stated, "If for no other reason than this human suffering, we would have to condemn this road to unity as criminal. But there is more to it than that. This is not simply a case of mass murder. It is a case of genocide, of destruction, not of individuals only, but of a culture and a nation" ("Soviet Genocide" 8).

The "fourth prong" of the genocide, Lemkin wrote, was the "fragmentation of the Ukrainian people" when after the social destruction caused by the famine, non-Ukrainians were resettled into the Ukrainian republic ("Soviet Genocide" 8). By the end of his speech, he returned to the idea that the annihilation of the nation and the Soviet attempt to destroy Ukrainian national patterns caused an irreplaceable loss to world civilization:

If it were possible to do this even without suffering we would still be driven to condemn it, for the family of minds, the unity of ideas, of language and of customs that form what we call a nation that constitutes one of the most important of all our means of civilization and progress. It is true that nations blend together and form new nations-we have an example of this process in our own country-but this blending consists in the pooling of benefits of superiorities that each culture possesses. What then, apart from the very important question of human suffering and human rights that we find wrong with Soviet plans, is the criminal waste of civilization and of culture. For the Soviet national unity is being created, not by any union of ideas and of cultures, but by the complete destruction of all cultures and of all ideas save one-the Soviet. (Lemkin, "Soviet Genocide" 8) 


\section{Works Cited}

Annus, Epp. "The Problem of Soviet Colonialism in the Baltics." Journal of Baltic Studies, vol. 43, no. 1, 2012, pp. 21-45. DOI: 10.1080/01629778.2011.628551

Bauer, Otto. The Question of Nationalities and Social Democracy. Edited by Ephraim J. Nimni, translated by Joseph O'Donnell, Minnesota UP, 2000.

Bronner, Stephen Eric. The Bigot: Why Prejudice Persists. Yale UP, 2014.

Corni, Gustavo. Hitler's Ghettos: Voices from a Beleaguered Society 1939-1944. Arnold, 2002.

Davies, Norman. Rising '44: The Battle for Warsaw. Viking, 2004.

Davies, R. W., and S. G. Wheatcroft. The Industrialization of the Soviet State. Vol. 5: The Years of Hunger: Soviet Agriculture, 1931-1933, Palgrave, 2004.

Davies, R. W., et al. "Stalin, Grain Stocks, and the Famine of 1932-1933." Slavic Review, vol. 54, no. 3, 1995, pp. 642-57. DOI: $10.2307 / 2501740$

Feierstein, Daniel. Genocide as Social Practice: Reorganizing Society under the Nazis and Argentina's Military Juntas. Translated by Douglas Andrew Town, Rutgers UP, 2014.

Galtung, Johan. "Violence, Peace, and Peace Research.” Journal of Peace Research, vol. 6, no. 3, 1969, pp. 167-91.

Goldberg, Amos. "The History of Jews in the Ghettos: A Cultural Perspective." The Holocaust and Historical Methodology, edited by Dan Stone, Berghahn Books, 2012, pp. 79-100.

Gutman, Israel. The Jews of Warsaw, 1939-1943: Ghetto, Underground, Revolt. Indiana UP, 1982.

Irvin-Erickson, Douglas. "Genocide Discourses: American and Russian Strategic Narratives of Conflict in Iraq and Ukraine." Politics and Governance, vol. 5, no. 3, 2017, pp. 130-45. DOI: 10.17645/pag.v5i3.1015.

---. "Genocide, the 'Family of Mind' and the Romantic Signature of Raphael Lemkin." Journal of Genocide Research, vol. 15, no. 3, 2013, pp. 273-96. DOI: 10.1080/14623528.2013.821222.

---. Raphaël Lemkin and the Concept of Genocide. Pennsylvania UP, 2017.

Jiménez de Asúa, Luis, et al., editors. Actes de la Vème Conférence Internationale pour l'Unification du Droit Pénal (Madrid 14-20 Octobre 1933). A. Pedone, 1935.

Jones, Adam. Genocide: A Comprehensive Introduction. Routledge, 2006.

Korey, William. An Epitaph for Raphael Lemkin. Jacob Blaustein Institute for the Advancement of Human Rights, 2001.

Kornat, Marek. "Polish Interpretations of Bolshevism and Totalitarian Systems (1918-1939)." Totalitarian and Authoritarian Regimes in Europe: Legacies and Lessons from the Twentieth Century, edited by Jerzy W. Borejsza et al., Berghahn Books, 2006, pp. 80-105.

Korostelina, Karina. "Crimean Tatars From Mass Deportation to Hardship in Occupied Crimea." Genocide Studies and Prevention, vol. 9, no. 1, 2015, pp. 33-47. DOI: 10.5038/1911-9933.9.1.1319 
Kraft, Claudia. "Nationalisierende Transnationalisierung: (Inter)nationale Strafrechtswissenschaft in der Zwischenkriegszeit." Leipziger Zugänge zur Rechtlichen, Politischen und Kulturellen Verflechtungsgeschichte Ostmitteleuropas, edited by Dietmar Müller and Adamantios Skordos, Leipziger Universitätsverlag, 2015, pp. 15-26.

Lemkin, Raphael (Raphaël Lemkin). "Akte der Barbarei und des Vandalismus als Delicta Juris Gentium.” Anwaltsblatt Internationales, vol. 19, 1933, pp. 117-19.

---. Autobiography. Raphael Lemkin Papers, Manuscript Collection 1730, Manuscript and Archives Division, New York Public Library, Reel 2, Box 1, Folder 36, "Introduction."

---. Axis Rule in Occupied Europe: Laws of Occupation, Analysis of Government, Proposals for Redress. Carnegie Endowment for International Peace, 1944.

---. "Les Actes Constituant un Danger General (interétatique) Considerés Comme Delits du Droit des Gens." Actes de la Vème Conférence Internationale pour l'Unification du Droit Pénal (Madrid 14-20 Octobre 1933), edited by Jimenez de Asua, et al., A. Pedone, 1935, pp. 48-56.

---. "Soviet Genocide in the Ukraine." New York Public Library, Reel 3, Box 2, Folder 16 , pp. 1-8.

---. Soviet Genocide in the Ukraine. Edited by L. Y. Luciuk, Kashtan Press, 2014.

---. Totally Unofficial: The Autobiography of Raphael Lemkin. Edited by Donna-Lee Frieze, Yale UP, 2013.

Lemkin, Rafał (Raphaël Lemkin). "Dzieje i charakter reform karnego we Włoszech." Kodeks karny faszystowski Włochy, Nakladem Ksiegarni F. Hoesicka, 1929, pp. 789.

---. Kodeks karny Rosji Sowieckiej 1927. Sklad Glowny w Ksiegarni F. Hoesicka, 1928.

---, and Tadeusz Kochanowicz. Kodeks karny republik sowieckich. Wyd. Sem. Prawa kar., 1926.

---. "Ustawodawstwo karne Rosji Sowieckiej, Kodeks karny, procedura karna." Encyklopedja podręczna prawa karnego, edited by Wacław Makowski, vol. 25, 1938, pp. 1581-87.

Lewis, Mark. The Birth of the New Justice: The Internationalization of Crime and Punishment, 1919-1950. Oxford UP, 2014.

Luciuk, Lubomyr Y. Holodomor: Reflections on the Great Famine of 1932-1933 in Soviet Ukraine. Kashtan Press, 2008.

Müller, Dietmar. "Zu den Anfägen des Völkerstrafrechts: Vespasian Pella und Raphael Lemkin." Leipziger Zugänge zur Rechtlichen, Politischen und Kulturellen Verflechtungsgeschichte Ostmitteleuropas, edited by Dietmar Müller and Adamantios Skordos, Leipziger Universitätsverlag, 2015, pp. 27-40.

Naimark, Norman. Stalin's Genocides. Princeton UP, 2010.

Nimni, Ephraim. Marxism and Nationalism: Theoretical Origins of a Political Crisis. Pluto Press, 1989.

Power, Samantha. A Problem from Hell: America and the Age of Genocide. Basic Books, 2002.

Rabinbach, Anson. "The Challenge of the Unprecedented-Raphael Lemkin and the Concept of Genocide." Jahrbuch des Simon-Dubnow-Instituts, vol. 4, 2005, pp. 397-420. 
Renner, Karl. "State and Nation." National Cultural Autonomy and Its Contemporary Critics, edited by Ephraim Nimni, Routledge, 2005, pp. 15-47.

Segesser, Marc Daniel, and Myriam Gessler. "Raphael Lemkin and the International Debate on the Punishment of War Crimes (1919-1948)." Journal of Genocide Research, vol. 7, no. 4, 2005, pp. 453-68. DOI: 10.1080/14623520500349902

Serbyn, Roman. "Lemkin on Genocide of Nations." Journal of International Criminal Justice, vol. 7, no. 1, 2009, pp. 123-30. DOI: 10.1093/jicj/mqp002

---. "The Ukrainian Famine of 1932-1933 as Genocide in the Light of the UN Convention of 1948." The Ukrainian Quarterly, vol. 62, no. 2, 2006, pp. 181-94.

Szawłowski, Ryszard. “Raphael Lemkin’s Life Journey: From Creative Legal Scholar and Well-to-Do Lawyer in Warsaw until 1939 to Pinnacle of International Achievements during the 1940s in the States, Ending Penniless Crusader in New York in the 1950s." Rafał Lemkin: A Hero of Humankind, edited by Agnieszka Bieńczyk-Missala and Sławomir Dębski, The Polish Institute of International Affairs, 2010, pp. 31-58.

Troebst, Stefan. "Lemkin and Lauterpacht in Lemberg and Later: Pre- and PostHolocaust Careers of Two East European International Lawyers." Institut für die Wissenschaften vom Menschen, 2013, http://www.iwm.at/read-listenwatch/transit-online/lemkin-and-lauterpacht-in-lemberg-and-later-pre-andpost-holocaust-careers-of-two-east-european-internationallawyers/\#_ftnref27. Accessed 6 Nov. 2020.

Trunk, Isaiah. Judenrat: The Jewish Councils in Eastern Europe under Nazi Occupation. Stein and Day, 1977.

United Nations Convention on the Prevention and Punishment of the Crime of Genocide. United Nations, 9 Dec. https://www.un.org/en/genocideprevention/documents/atrocitycrimes/Doc.1 Convention\%20on\%20the\%20Prevention\%20and\%20Punishm ent $\% 20$ of $\% 20$ the $\% 20$ Crime $\% 20$ of $\% 20$ Genocide.pdf. Accessed 5 Nov. 2020.

von Hagen, Mark. "From Imperial Russia to Colonial Ukraine." The Shadow of Colonialism on Europe's Modern Past, edited by R. Healy and E. D. Lago, Palgrave, 2014, pp. 173-93. Cambridge Imperial and Post-Colonial Studies Series.

Vyshinskii, A. Ia. "Predislovie." Ugolovnaia interventsiia. Dvizhenie po unifikatsii ugolovnogo zakonodatel'stva kapitalisticheskikh stran, by A. N. Trainin, Gosudarstvennoe Izdatel'stvo Sovetskoe Zakonodatel'stvo OGIZ, 1935, pp. 3-6.

Weiss-Wendt, Anton. The Soviet Union and the Gutting of the UN Genocide Convention. Wisconsin UP, 2017. 